\author{
Milena Škobo* \\ Sinergija University, Bijeljina, Bosnia and Herzegovina
}

\author{
Sanja Stojković Zlatanović** \\ Institute of Social Sciences, Belgrade, Serbia
}

\title{
THE SOCIAL, CULTURAL AND LEGAL ASPECTS OF LABOUR MIGRATIONS FROM SERBIA TO CANADA
}

\begin{abstract}
The aim of this paper is to explore social, economic and cultural challenges of migrations to Canada by providing the Canadian policy framework regarding employment and working conditions of migrant workers. The labour status of those with high-professional capacities (teachers, artists, health care professionals, IT professionals, scientists, etc.) will be particularly addressed in this paper, taking into account a recent Serbian policy of "brain drain" management. The positive potential of migration expressed in development-friendly migration policy needs to be considered since migrant policies also affect both countries' socioeconomic and cultural development. Serbian Diaspora Act (2009) and the National Strategy for Preserving and Strengthening the Relations between the Homeland and the Diaspora and the Homeland and Serbs in the Region (2011) will be used as basic referential legal documents.
\end{abstract}

\section{Keywords}

Migrations, social, economic and cultural challenges, brain drain phenomenon, push and pull factors, migrant workers.

\footnotetext{
*milenanikolic86@yahoo.com

**sanjazlatanovic1@gmail.com
} 


\section{Introduction}

Why do people decide to leave the country of origin? How does an individual choose the country where he/she would like to immigrate to? What are the most important push and pull factors ${ }^{1}$ that determine one's opinion to change his/ her life and seek better future in another country? These are the most frequent questions that come to mind when thinking about migrations in the $21^{\text {st }}$ century. According to International Organization for Migrations (IOM, 1999), there are five pull factors that attract people to immigrate to another country, that is, the country of destination: better life conditions, higher earnings, other people's experience with migration, good chances for employment, and greater degree of individual freedom. IOM singles out two push factors that make people leave the country of origin: ethical issues (unequal approach to basic human rights, health care, education and social protection) and economic problems in the country of origin.

The latest statistical data, referring to 2011, have shown that there is a falling trend of emigration from Serbia to so-called traditional immigration countries such as Sweden and France, and rising trend of immigration to new destinations such as Hungary, Russia, and Great Britain; also, there is still an ongoing trend of intensive immigration to Canada, the USA and Australia (Bobić et.al 2016: 22). In the period between 1971 and 2011 the number of people who left Serbia and immigrated to Canada almost tripled (from 2,865 to 6,226); (Stanković 2014: 23).

Why do the citizens of Serbia choose Canada as a desirable destination country? In the first part of the paper, we identified and analyzed socieoeconomic and cultural aspects of labour migration with special focus on brain-drain phenomenon in Serbia, while the second part of the paper deals with legal framework regarding Canadian Immigration policy and the Agreement on Social Security between Canada and the Republic of Serbia concluded in 2013.

\section{Socioeconomic and cultural challenges of labour migration from Serbia to Canada}

One of the most important questions regarding migrations of people from Serbia to Canada is why the country has a high emigration and low immigration potential. In order to address this matter adequately, we shall rely on the findings of the Second National Report on Social Inclusion and Poverty Reduction in

1 Push factors are related to the conditions in the country of origin, predominantly negative, that make people leave. Pull factors are related to the conditions in the country of destination, they "attract" people and make them think they can satisfy their needs. 
Serbia conducted in $2014 .{ }^{2}$ The findings have indicated that a total of $42.1 \%$ of the population of the Republic of Serbia is at risk of poverty or social exclusion. In particular, it has been determined that risk of poverty, low work intensity and severe material deprivation have been the main factors that lead to social exclusion. These factors also affected people's decision to leave the country of origin and seek better future elsewhere. This is particularly true of younger population who has difficulties with finding a proper job even after graduation. Namely, the youth activity rate has been recording a protracted downward trend, and the youth unemployment rate has surged since the onset of the crisis - from $35.1 \%$ in 2008 to $49.4 \%$ in 2013 (Rašević 2016: 32). Also, our educational system still has lower outcomes compared to international average, while the unemployment rate of older workers and persons with lower level of education has been on the rise in recent years (Rašević 2016: 33).

Another important thing to take into consideration when it comes to reasons for emigration is a country's ability to secure democracy and freedom. According to the 2019 Freedom House Report, Serbia has been included among partly free countries and it has received the score 3 on the scale from 1 to 7 , with 1 being maximum and 7 minimum degree of respect for civil liberties and political rights. ${ }^{3}$ Also, there has been a falling trend od media freedom in Serbia recently (Nikolić 2018: 265). On the other hand, Canada has received the score 1 as a free country with a strong history of respect for political rights and civil liberties, and generally free media. ${ }^{4}$

Also, socioeconomic development of Serbia is another indicator relevant to migration. According to the 2018 Human Development Index (HDI) that measures progress in three basic categories of human development such as long and healthy life, access to knowledge and decent living standard, Serbia ranked $67^{\text {th } 5}$ out of 189 countries, while Canada ranked $12^{\text {th }} .6$

The findings of two empirical studies ${ }^{7}$ conducted between 2010 and 2014 have shown that the priority motives of the residents of Serbia to move to a foreign

${ }^{2}$ http://socijalnoukljucivanje.gov.rs/wp-content/uploads/2014/11/Second-National-Report-on-Social-Inclusion-and-Poverty-Reduction-fi nal.pdf

3 https://freedomhouse.org/report/freedom-world/2019/serbia

4 https://freedomhouse.org/report/freedom-world/2019/canada

5 http://hdr.undp.org/sites/default/files/2018_summary_human_development_statistical_ update_en.pdf

${ }^{6}$ http://hdr.undp.org/en/countries/profiles/CAN

7 The first research is Territorial Capital in Serbia: Structural and Action Potential of Local Development implemented by the Institute of Sociology and Social Research of the Faculty of Philosophy, University of Belgrade during 2013 and 2014. The second research is conducted by the Centre for Free Elections and Democracy in 2010 and 2013, within the PBILD - South Serbia UN Joint programme Strengthening Capacity for 
country are unempoloyment, economic difficulties and the individual perception of the respondents that other societies enable a better quality life (Rašević 2016: 35). The population aged between 15 and 30 has also listed better working and living conditions as the main motives for emigrating from Serbia.

Modern migration flows are important part of the globalization process and they include the flow of ideas, cultural goods and people. With the increasing number of migrants, social and cultural characteristics of migrations multiply and the distinction between migration spaces becomes blurred. Modern world is characterised by both cultural and linguistic differences. Labour mobility and emigration have led to the need for understanding different languages and cultures and establishing closer relations between people of different ethnic origin. Such "cosmopolitanism" triggered a new form of behaviour (Vertovec, Cohen 2001). On the other hand, nationalism, religious fundamentalism, racism and other forms of social exclusion are on the rise. Inability to adequately address the challenges resulting from the process of globalization (i. e. new ethical and cultural needs, constant expansion of the market) has led to inability to create a unique and acceptable form of ethnic and cultural identity in the new environment. Diaspora, as a form of social organization, through its activities, may consolidate and reconcile these two confronted sides of the same process (Despić 2015: 12).

Establishing relationship between the country of origin and its intelectual diaspora might be of crucial importance in regard with improving the country's socioeconomic problems and tackling its cultural challenges. According to Jovan Filipović, the professor at the Faculty of Organizational Sciences in Belgrade, who has conducted an empirical study on Serbian diaspora, the greatest number of highly educated professionals from Serbia (Serbian intelectual diaspora) live in the USA (39\%) and Canada (15\%); (Filipović 2012: 146-148). Namely, Filipović created a model of Serbian Diaspora Virtual University (SDVU), a sort of a cyber space/network designed to promote gathering, exchanging and activation of potential knowledge of experts from diaspora and their colleagues/ partners/friends/family/peers/scholars in the country of origin. The purpose of this model of connecting migrants with their country of origin (Serbia) is creating innovative solutions to the existing problems in the country of origin on the basis of implementing transnational experience of the members of the network (Filipović 2012). The results of this study have shown that the SDVU model that supports tertiary education without borders proved to be extremely positive in terms of promoting of human capital, cherishing cultural norms and positive attitudes, accepting democratic values and ensuring circulation of knowledge based on transnational experience.

Inclusive Local Development in South Serbia and Promotion of Peace Building in South Serbia. 
Also, Canada is seen as a desirable destination country since it promotes ethnic diversity and multiculturalism through its developed immigration-friendly policy. It is one of the leading countries when it comes to the level of integration of immigrants and their economic and social inclusion (Despić 1015: 200). The biggest number of people from the Balkans that chose Canada as their destination country was during the war period in the 90s. The results of the survey conducted in the form of an online questionnaire in 2008 showed that highly educated individuals decided to leave Serbia for Canada and the USA in the 1990s due to the uncertain future, negative outlook for children's future, low living standards and war (Despić 2015: 186-189). After 2000, highly educated persons, experts and talents singled out professional and individual self-realisation as one of the most important motives to emigrate from Serbia to Canada, apart form unsatisfactory economic situation.

The results of several case studies have indicated that the majority of educated immigrants from different countries, including Serbia, has been satisfied with both living and working conditions in Canada (Meyer 2001, Hugo 2006, Despić 2015). The findings of several case studies conducted in Serbia (Despić 2015) have shown that Canada puts lots of effort to help immigrants to adapt to new living conditions, particularly in terms of their equality before law, confidence in state institutions, promotion and respect of their ethnic, religious and cultural differences and the country's stability. Also, Serbian immigrants in Canada are encouraged to feel comfortable and accepted since the country provides assistance with language learning, job seeking, citizenship acquirement, etc. Some of the respondents in the survey highlighted the existance of "multicultural societies" that help immigrants in various fields (i.e. giving legal advice, providing translators, etc.) or the fact that non-party members can easily get jobs (Despić 2015: 202). When asked to list positive things about living in Canada, they singled out the following: perspective future, high living standard, the country's good social policy, high possibility of getting/choosing a job, good working conditions and possibility of getting promoted. Negative aspects of living in Canada from the perspective of immigrants are loneliness (all of them miss family and friends from Serbia), pressure and fast living. Also, cultural differences (food, drinks, entertainment, children upbringing, etc.) are listed as something they have difficulties with.

\section{Migration management policy issues regarding the status of skilled workers from Canadian and Serbian perspective}

Canada could be recognised as one of a highly desirable destination for foreign workers, both for those classified as temporary and permanent immigrants. According to the OECD document, Canada is widely perceived as a model for 
successful management of migration, particularly their model introduced for skilled workers with high professional qualifications. ${ }^{8}$ Like the most developed countries, Canada focuses on the policy measures attracting workers who own at least Bachelor University degree, have a superior level of experience and excellent language skills in order to boost economic growth. According to the statistics data from 2008, skilled workers accounted for $60.3 \%$ of those admitted as permanent residents (Preibisch, Hennebry 2011: 1033).The accomplishment of settled economic and social goal has led to the reform of the Canadian immigration system conducted in the last four years. The intention of the policymakers was to make the best linkage between the potential (skilled) immigrant workers and labour market demands. The Canadian migration management policy is based on the assimilation of skilled workers in the workplace and in the society answering to the labour market needs in order to reach the economic goals. The main reason for the reform was the lack of assimilation of skilled workers in the domestic labour market where the Canadian policymakers noticed the failure of the traditional point system (Oreopoulos 2011: 149). The unemployment rates of skilled immigrant workers compared to similarly aged non-immigrants was almost twice as high (Oreopoulos 2011: 148). Accordingly, the discrimination practice, particularly indirect discrimination, was addressed in recent research studies, where most employers expressed languages skill concerns based on applicant personal name (Oreopoulos 2011: 169). It led to the new policy and legal framework regarding the recruitment of immigrant workers in the Canadian labour market.The most important change has been the implementation of the so-called Express Entry Programme- the new selection system for permanent labour migration, introduced in 2015. The system is founded upon the clearly determined criteria of one of pre-existing federal economic skilled programmes (Canadian Experience Class (CEC), Federal Skilled Worker (FSW), or Federal Skilled Trades (FST) programme) as well as the core requirements regarding qualification level, skilled work experience and languages knowledge. ${ }^{9}$ Express Entry Programme is flexible in its nature, where selection system accounts not only the individual characteristics of the candidate but also the interaction of the characteristics, for instance, doctoral degree with additional language skills (French and English), giving the additional points to this combination. ${ }^{10}$ Furthermore, skilled workers with a job waiting are given additional points compared with those in arranged employment, which represents a specific model

8 Hiring for success - Challenges for Canada's Labour Migration System, OECD, November 2016,4 .

9 Hiring for success - Challenges for Canada's Labour Migration System, OECD, November 2016, 9 .

${ }^{10}$ Hiring for success - Challenges for Canada's Labour Migration System, OECD, November 2016, 9 . 
of positive action policy (antidiscrimination policy) for the immigrant worker as a vulnerable category of workers.

On the other hand, developing countries and countries in transition like Serbia have recently been dealing with the emigration issues of skilled workers, traditionally called the phenomenon of brain drain. The phenomenon in Serbian literature is defined as an exodus of the brain, that has been recently designated, especially since the 1960s, regarding the migration of highly educated and skilled workers, particularly, scientists, engineers and doctors with the intention to be permanently settled in a foreign country (Despić 2015: 16). Although the issue of brain drain has dominantly been considered as negative, the contemporary approaches in migration policy regarding skilled workers in developing countries have changed. The focus is on increasing recognition of the potential importance of migration and brain drain to the development of the country of origin. It results in the introduction of the systematic model of migration policy, the so-called development-friendly migration policy. There is no universally accepted definition of development-migration policy concept but it could be understood as "migration from the developing to the developed world that play an important role in the development of the poorer countries of origin" (Skeldon 2008: 1-18). A significant element of migration and development policy in terms of globalization is the diaspora's agenda, i. e. the flow of investment and know-how to countries of origin from diasporas has often been highlighted as being particularly beneficial from a development perspective (Chappell, Glennie 2009: 11, 3). It means that emigration could be beneficial for the country of origin in terms of transfers regarding remittances, skills and investments.

Serbia adopted Diaspora Act in 2009 and the National Strategy for Preserving and Strengthening the Relations between the Homeland and the Diaspora and the Homeland and Serbs in the Region in 2011, which is considered as the basic legal framework representing development-friendly migration concept in domestic terms. After the USA and Germany, Canada is in the third place, taking into account the number of persons with Serbian nationality, accounting approximately 250000 people. ${ }^{11}$ Serbian Diaspora Act ${ }^{12}$ (2009) is a basic law that regulates issues regarding the models of preserving, strengthening and achieving connections between the diaspora, i.e. persons with Serbian nationality permanently settled in a foreign country and a country of origin. The principal measure of importance for the status of Serbian people leaving

${ }^{11}$ The National Strategy for Preserving and Strengthening the Relations between the Homeland and the Diaspora and the Homeland and Serbs in the Region, Republic of Serbia, Ministry of Religion, Belgrade: 2011, 3.

${ }^{12}$ Law on diaspora and Serbs in the Region, Official Gazete of the Republic of Serbia, No. $88 / 2009$. 
abroad is bilateral and multilateral agreements concluded between the Republic of Serbia and a particular country in order to improve the status and protect the basic rights of emigrants. Of special importance are the agreements in the field of social security, where Serbia and Canada in 2013 concluded the Agreement on Social Security between Canada and the Republic of Serbia (E105293). The Agreement deals with issues regarding the Canadian pension and old age security provisions compared with Serbian pension and disability insurance as well as insurance for work-related accidents and occupational diseases that have been harmonized.

The Serbian framework of development-friendly migration policy, particularly in terms of brain drain, could be considered through the content of the National Strategy for Preserving and Strengthening the Relations between the Homeland and the Diaspora and the Homeland and Serbs in the Region (2011). The special part of the Strategy has been devoted to the issue of strengthening the scientific, technological, cultural, educational, sports and other development of the country - the use of knowledge and skills of the highly educated labor force that has left the Republic of Serbia, in terms of teleworking i.e. promoting remote work. The negative impact of brain drain on the Serbian economic growth is detected, together with the demographic trends showing high emigration and reduced fertility rates, where the mitigation measures are introduced by the Strategy as a part of the development-friendly migration policy. The Republic of Serbia is devoted to the development of special programs regarding the return of experts, circulation of temporary employment contracts (brain circulation), funding summer camps, providing professional support and consultation in terms of straightening the connection between the country of origin and high skilled emigrants. The special programs will be implemented under the model of institutional cooperation between states, where emigrants need to preserve their careers abroad but give support to the domestic economy and development of the society as well. Serbia will create the national information database of highly-educated emigrants encouraging the mutual networking of Diaspora members by professions and with appropriate professions in the Republic of Serbia.

\section{Conclusion}

Modern society triggers mobility of the youth and highly educated professionals. Mobility in this sense is perceived as positive only if it is circular, that is, only if people with high-professional capacities plan to come back to the country of origin. As a country with a very high level of emigration of the youth and highly educated people, Serbia unfortunately faces brain-drain phenomenon. Despite the fact that Serbian diaspora wishes to come back to the country of 
origin, there are still many issues Serbia has to deal with. Namely, the scientific and professional communities are not open enough to accept diaspora and returnees, there are no proper transnational activities, and there is no adequate support from the country regarding the knowledge circulation and brain-drain (Pavlov, Polovina 2011, Bobić et al., 2016: 30).

The problem of brain-drain phenomenon in Serba might be resolved by promoting Filipović's model of SDVU that might turn brain-drain into brain-gain since it supports education-without-borders concept (distance learning programs, e-libraries, corporative universities, etc). This concept leads to promoting human capital, accepting democratic values and positive attitudes, and cherishing cultural values and norms through the exchange of transnational experience and knowledge between migrants and its counterparts in the country of origin. Furthermore, the fact that the concept of distance learning has not been properly developed in Serbia, particularly in the fields of social sciences and humanities, further deepens the complexity of the problem of brain-drain. Providing the adequate model of online teaching courses as an alternative to face-to-face teaching might result in a downtrend in brain-drain.

Canada is a country with developed Immigration-friendly politics, particularly the model introduced for skilled workers with high professional qualifications. The status of persons with Serbian nationality living in Canada is defined by the Agreement on Social Security between Canada and the Republic of Serbia (E105293) concluded between Canada and Serbia in 2013. Having in mind the fact that there are approximately 250,000 people with Serbian nationality living in Canada, emigration to Canada could be beneficial for Serbia in terms of transfers regarding remittances, skills and investments. Serbia is devoted to the implementation of special programs, where emigrants can simultaneously preserve their careers abroad and support the domestic economy and the country's prosperity. Still, a lot has to be done regarding strenghtening the connection between the country of origin and high-skilled emigrants, supporting the return of the experts and promoting brain circulation.

\section{WORK CITED}

Bobić, Mirjana, Vesković Anđelković Milica, Kokotović, Vlasta. Studija o spoljnim i unutrašnjim migracijama građana Srbije sa posebnim osvrtom na mlade [Study on Externaland InternalMigration of Serbia's Citizens with Particular Focus on Youth].Beograd: IOM, 2016.

Chappell, Laura, Glennie, Alex. Maximising the Development Outcomes of Migration: A Policy Perspective. United Nations Development Programme, Human Development Reports, Research Paper, 2009/11. 
Despić, Jelena. Migracije visokoobrazovanih lica iz Srbije od 1991. godine u Kanadu i Sjedinjene Američke Države. Doktorska disertacija. Beograd: Ekonomski fakultet Univerziteta u Beogradu, 2015.

Filipović, Jovan. Management of Diaspora Virtual University as a Complex Organization. SerbianDiaspora Virtual University: An Emerging Leadership of a Nation, LAP: Lambert Academic Publishing, 2012.

Hugo, Graeme. "The Pattern of Skilled Migration flows: today and tomorrow: A View from Asia". Paper presented to Immigration Futures Forum, Monash University Centre, Prato, Italy, 17-19 May, 2006.

Meyer, Jean-Baptiste. "Network Approach versus Brain Drain: Lessons from the Diaspora”, International Migration, 39(5), 2001, 91-110.

Nikolić, Z. Milena. Serbia in British and American media, Security, Political and Legal Challenges of the Modern World: conference proceedings, Vol. 1/ International scientific conference, Bitola, 19-21 October, 2018; (Eds. Svetlana Nikoloska, Angelina Stanojska), Bitola: University "St. Kliment Ohridski", 258-268.

Oreopoulos, Philip. "Why Do Skilled Immigrants Struggle in the Labor Market? A Field Experiment with Thirteen Thousand Resumes". American Economic Journal: Economic Policy, 3 (November 2011).

IOM, Migration potential in Central and Eastern Europe. Geneva: International Organisation forMigration, 1999.

Pavlov Tanja, Polovina, Nada.Mobility and Emigration of Professionals. Personal and Social Gains andLosses, Group 484, Belgrade: Institute for Educational Research, 2011.

Preibisch, Kerry, Hennebry, Jenna. "Temporary migration, chronic effects: the health of international migrant workers in Canada." CMAJ, 183(9) 1 (2011).

Rašević, Mirjana. Migration and Development in Serbia.Belgrade: International Organization for Migration (IOM), 2016.

Skeldon, Ronald. "International Migration as a Tool in Development Policy: A Passing Phase?”. Population and Development Review, 34-1 (2008), 1-18.

Stanković, Vladimir. Srbija u procesu spoljnih migracija. Popis stanovništva, domaćinstava i stanova 2011. u Republici Srbiji. Beograd: RSZ, 2014.

Vertovec, S., Cohen, R. Religion and Diaspora, Working Paper, Transnational Communities Programme.University of Oxford, 2001.http:/www.transcomm. ox.ac.uc/working\%20papers/Vertovec01.pdf

Hiring for success - Challenges for Canada's Labour Migration System, OECD, November 2016. 
The National Strategy for Preserving and Strengthening the Relations between the Homeland and the Diaspora and the Homeland and Serbs in the Region. Belgrade: Republic of Serbia, Ministry of Religion, 2011.

Law on diaspora and Serbs in the Region, Official Gazete of the Republic of Serbia, No. $88 / 2009$.

http://socijalnoukljucivanje.gov.rs/wp-content/uploads/2014/11/Second-National-Report-on-Social-Inclusion-and-Poverty-Reduction-final.pdf

https://freedomhouse.org/report/freedom-world/2019/serbia

https://freedomhouse.org/report/freedom-world/2019/canada

http://hdr.undp.org/sites/default/files/2018_summary_human_development_statistical_update_en.pdf 